\title{
内分泌攪乱物質問題に関する日本化学工業協会の見解と取り組み
}

\author{
社囘法人日本化学工業協会 エンドクリンワーキンググループ 川＼cjkstart崎－
}

\section{View and Measures of Japan Chemical Industry Association on "Endocrine Disruption Issue"}

Hajime Kawasaki

Chairman of the Endocrine Working Group, Japan Chemical Industry Association

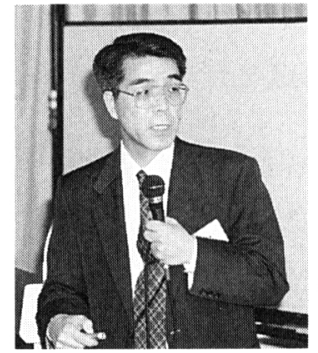

The exaggerated response to "endocrine disrupter (ED) issue" by mass media appears to have been calmed down recently due to the rational and cool views on this issue by the governments in Japan, USA as well as European Community. In this report, the official views and policies on ED issue of the governments are summarized. Since the testing method to distinguish the candidate EDs from non-ED chemcials is a matter of the highest prioity, the strategy for screening of candidate EDs from enormous number of daily-use chemicals and the state of testing method development are also noted. The views of both domestic and foreign chemical industries and the way how they participate the research works on this issue are mentioned.

分類 : $X_{1}$ 環境総論, $Z_{1}$ 産業・経営総論

\section{1.はじめに}

日本では, 1997 年 9 月にコルボーン博士らによる “奪われし未来”が翻訳出版されたことを契機に「内分 泌攪乱物質問題」がマスメディアに大きく取り上げら れ，国民の不安が高まっている。しかし，1998 年 11 月 に厚生省の「内分泌かく乱化学物質の健康影響に関す る検討委員会一中間報告書 ${ }^{1)}$ が公表されたことと同 年 12 月に環境庁主催の内分泌攪乱物質問題に関する 京都国際シンポジウムが開催されたことにより現在で はやや落ち着きを取り戻しているように見える。ここ では, 内分泌攪乱物質問題について各国行政機関の考 え方と対応方針, 日本化学工業協会の見解，それにこ の問題の将来展望について述べる。

\section{2.内分泌攪乱物質とは?}

「内分泌㩭乱物質」は，世界保健機構（WHO）ある いは国際化学物質安全性計画 (IPCS) の定義によれば 「内分泌系 (ホルモン系)」を「攪乱」し，「混乱あるい は崩壊」させる化学物質を指すが,「内分泌系に何らか の作用を持つ」化学物質という風に拡大寸る考方方も ある。しかし，「内分泌系に何らかの作用を持つ」化学 物質は, 我々の身の回りには数多く見られ, 例えば, 大豆などの食品中に存在する植物エストロジェンなど はその典型であるが，必ずしも「内分泌攪乱作用」を 持つわけではない。

「内分泌系の混乱あるいは崩壊」とは「人や野生生物 の生殖，発生などの局面における“種の存続”に関わ るような傷害性の影響」を指す1)。特に，人では，「子 
宮癌, 子宮内膜症, 乳癌, 精子数の減少, 前立腺癌, 精巣癌，尿道下裂など」を引き起こすことを言う。例 えば，妊婦が流産防止の目的で「ジエチルスチルベス

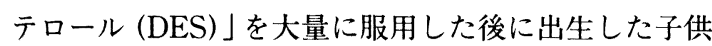
に「生殖器の形態異常」や「胵癌」が高頻度で発生し たとされるケースがそれである。また，野生生物にお いては，環境污染物質によると考えられる各種の生殖 異常が観察されており，DDT，PCB，トリブチルスズ といった国内ではすでに禁止されている化学物質ある いはダイオキシンのように意困しない生産物などによ る可能性が高いことが示されている。

なお，DESの場合は，5百万人もの妊婦が服用した こともあり， DESの子宮内暴露によるヒト（胎児） の影響に関する多くの調查がある。最近, 西川がこれ らをあらなめて解析している2)。これによれば子宮内 暴露により「内分泌攪乱」が引き起こされたのは妊婦 が DES を大量に捸取した場合だけであり，ある量を 超えなければ，そのような作用は認められていない。 従って, 少なくともヒトの場合は, DESのような強力 な女性ホルモン作用を持った化学物質を少量捸取した からといって直ちに「内分必攪乱」が引き起こされる わけではない。

\section{3. 日本政府の見解}

日本では，内分泌攪乱物質問題について厚生省およ び環境庁が公式に見解を発表している。人の健康への 影響については, 前出の厚生省「内分泌かく乱化学物 質の健康影響に関する検討委員会一中間報告書」(1998 年 11 月) ${ }^{1)}$ に，また，環境への影響については環境庁 「外因性内分泌攪乱物質問題への環境庁の対応方針に ついて 一環境ホルモン戦略計画 SPEED’98」(1998 年 5 月) ${ }^{3)}$ にまとめられている。これらの中で, 厚生省 の報告書について述べる。

厚生省の見解では, (1)生体内ホルモンの分泌と代謝 は高度に調節され，常時一定の適当な条件下にあるも のと考えられ, (2)内分泌攪乱物質の多くは, ホルモン 受容体に対する結合親和力が低いこと, (3)環境中の濃 度も一般的に低いレベルのものが多いことから, 直ち に有害反応を引き起こす可能性は低い, としている。 また, 「現在のところ, 内分泌攪乱物質の暴露と直接の 因果関係が指摘されている疾患群のうち, 子宮内膜症, 乳がん, 男性生殖器の発育異常などについて, 有意な 因果関係を示す知見はない」としている。ただし，胎 児への影響については, 成人のように内分泌系の フィードバックシステムが確立されていないことや, 化学物質の暴露経路が異なることなどから, その総合
的な暴露等について調査する必要があり，また，複数 の化学物質による相互作用や低用量における反応性に ついては, 現在のところ, 結論を出し得るだけのデー 夕に乏しくさらなる調査・研究が必要であるとしてい る。

また，「内分泌攪乱物質問題には, 多くの不確実さが 存在しているので, この問題を適切に解決するために は，科学的に十分信頼できる調查研究が必要である」 とも述べている。この不確実さとは,「内分泌攪乱物質 を問題とした報告は, しばしば, 再現性試験の結果, その再現性が認められないことが報告されていること や，試験管内でみられた実験結果が実験動物での試験 結果と矛盾する場合も多く報告されている」ことを指 しており，内分泌攪乱物質問題に関する論文について は内容を慎重に吟味する必要があることを示唆してい る。

なお, この報告書では, 食品用プラスチック容器の 原材料であるポリカーボネートから溶出するビスフェ ノール A，ポリスチレンから溶出するスチレン・ダイ マー, トリマー, ポリ塩化ビニルから溶出するフタル 酸エステルの評価結果も併せ報告されており, それに よれば食品用容器材料として一般に用いられている合 成樹脂のうち, ポリカーボネート，ポリスチレンおよ びポリ塩化ビニルの内分泌攪乱作用について,「人の健 康に重大な影響が生じるという科学的な知見は得られ ておらず, 現時点で直ちに使用禁止等の措置を講ずる 必要はないものと考えられる」と結論している。ただ し, 「内分泌攪乱化学物質の問題は, その作用の有無, 種類, 程度等について未解明な点が多いため, 引き続 き調査研究を推進していくことが重要であると考えら れる」とされている。これは，「ただし書き」つきなが ら, 現在得られているビスフェノール $\mathrm{A}$, スチレンモ ノマー, ダイマー, トリマーおよびフタル酸エステル に関する毒性およびプラスチックからの溶出量から推 定した人への暴露量に関する知見を化学物質の定量的 なリスクアセスメントの手法に従って科学的に評価し た場合, 人の健康への影響はないと判断したものと考 えられる。

\section{4. 米国政府の見解と対応}

環境庁 $(\mathrm{EPA})$ は, 1997 年 2 月に内分泌攪乱物質に 関する最初の報告書である「環境内分泌攪乱物質問題 に関する特別報告：作用評価と解析」4) 公表した。そ れによれば，(1)野生生物に対しては，ある種の農薬， ヒト女性ホルモン, 合成女性ホルモン, 有機スズ化合 物，ダイオキシン，PCBによると思われる影響があ 


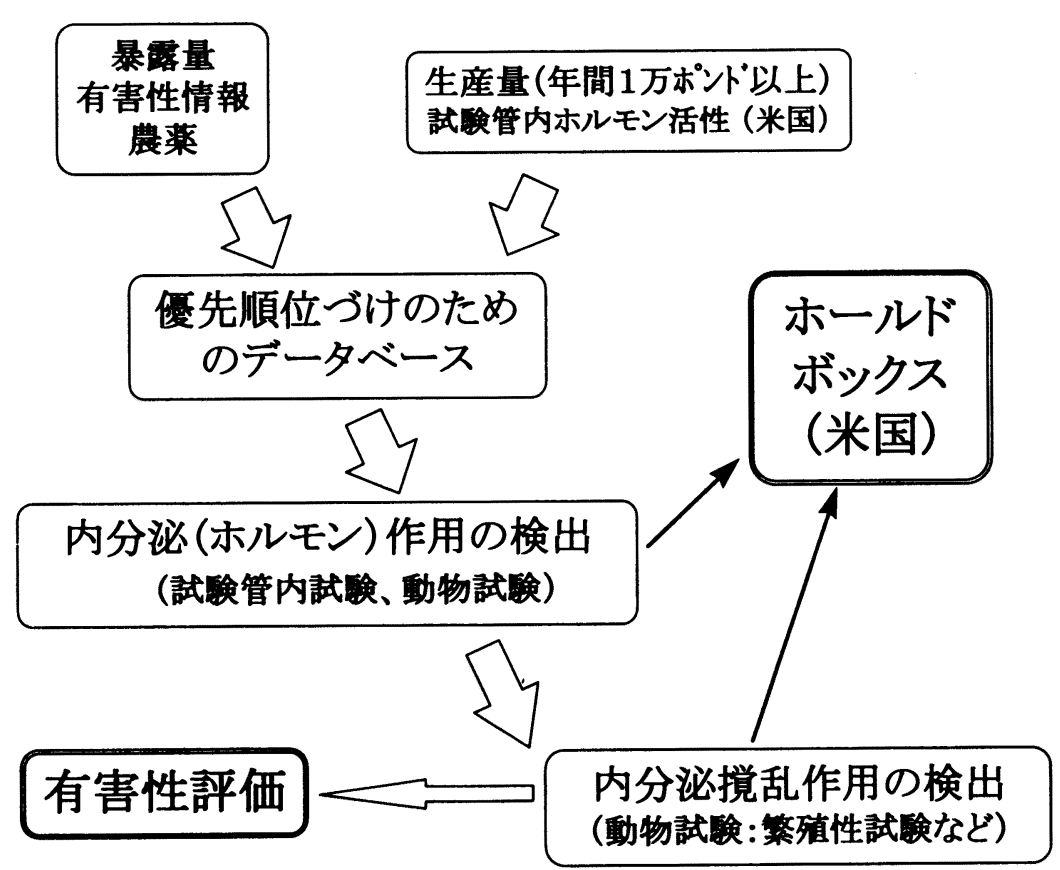

図 1 内分泌攪乱物質を選別する考之方（戦略）

る。しかし，ミンクやアザラシで見られた PCB やダイ オキシンによる繁殖影響については必ずしも内分泌挸 乱によるものとは判定していない。(2)人への影響では 合成女性ホルモン郕である DESなどのごく一部を除 いて明確な健康有害作用はなく，さらにネズミなどへ の実験室曝露ではオスでの精子形成や繁殖器官形成異 常が見られるものの現在の暴露濃度では人での影響を 特定する根拠にそしいとしている。特に，成人では， 食事由来で自然環境由来の内分泌（ホルモン）活性を 持った物質に曝露されても内分泌攪乱を防御しうるメ カニズムを持つことなどから現在の暴露濃度では, 恐 らく悪影響を受けることはないであろうとしている。 ただ，防御力の弱い胎児や乳児についても大人と同じ 程度に十分な防御機構をもつものかどうかについては 更なる情報が必要であるとしている。

\section{5. 欧州委員会 (EC) の見解と対応}

第 24 局（消費生活関連）は，本年 3 月に内分泌攪乱 物質に関する見解 ${ }^{5}$ を公表したが, それによると,内分 泌攪乱物質によるとされるヒト健康への影響（精子数 の減少, 精巣腫瘍, 前立腺癌, 乳癌の増加, 男子新生 児数の減少など）については，因果関係は明らかでは ない。ただし, 事故により $\mathrm{PCB}$ な゙へ高濃度暴露され た好婦から生まれた子供にみられる身体と精神の遅延 は，これらの有機塩素化合物による甲状腺ホルモン系
への影響による可能性がある，としている。一方，環 境生物においては, イボニシでのインポセックス（ト リブチル・スズ), 鳥の卵殼が薄くなる現象 (DDE), バルチック・アザラシの生殖と免疫に対する有害影響 $(\mathrm{PCB})$, 米国フロリダにおけるワニの生殖器の発達異 常 (DDT) などは，内分泌攪乱作用のある環境污染物 質によるもので, 内分泌攪乱物質はヒトに対してょり も環境に対する影響が強く，重大であるとしている。

\section{6. 内分泌㩧乱物質の評価方法}

現在，内分泌攪乱物質問題で各国政府が最も力を入 れているのは，化学物質の内分泌攪乱作用を評価する 方法（スクリーニング試験と判定試験）の確立である。 これは, 日米欧の政府, 産業界および環境保護団体な どが協調して推進しており，現在では概略の戦略がま とまっている。

現在，考え方が最も良く整理されている米国の内分 泌攪乱物質検出のための戦略6,7) まとめると (図 1)，(1「内分泌（ホルモン）作用」あるいは「内分泌攪 乱作用」を持つ可能性の高い化学物質を文献情報をも とに分類し，さらに生産量や暴露デー夕を加味してス クリーニング試験にかける優先順位を決める（第一次 分類）。次いで，(2)「内分泌攪乱作用」の一要素である 「内分泌 (ホルモン) 作用」を簡便な方法で判定し, 次 の「内分泌攪乱作用」を判定する試験へ供する化学物 


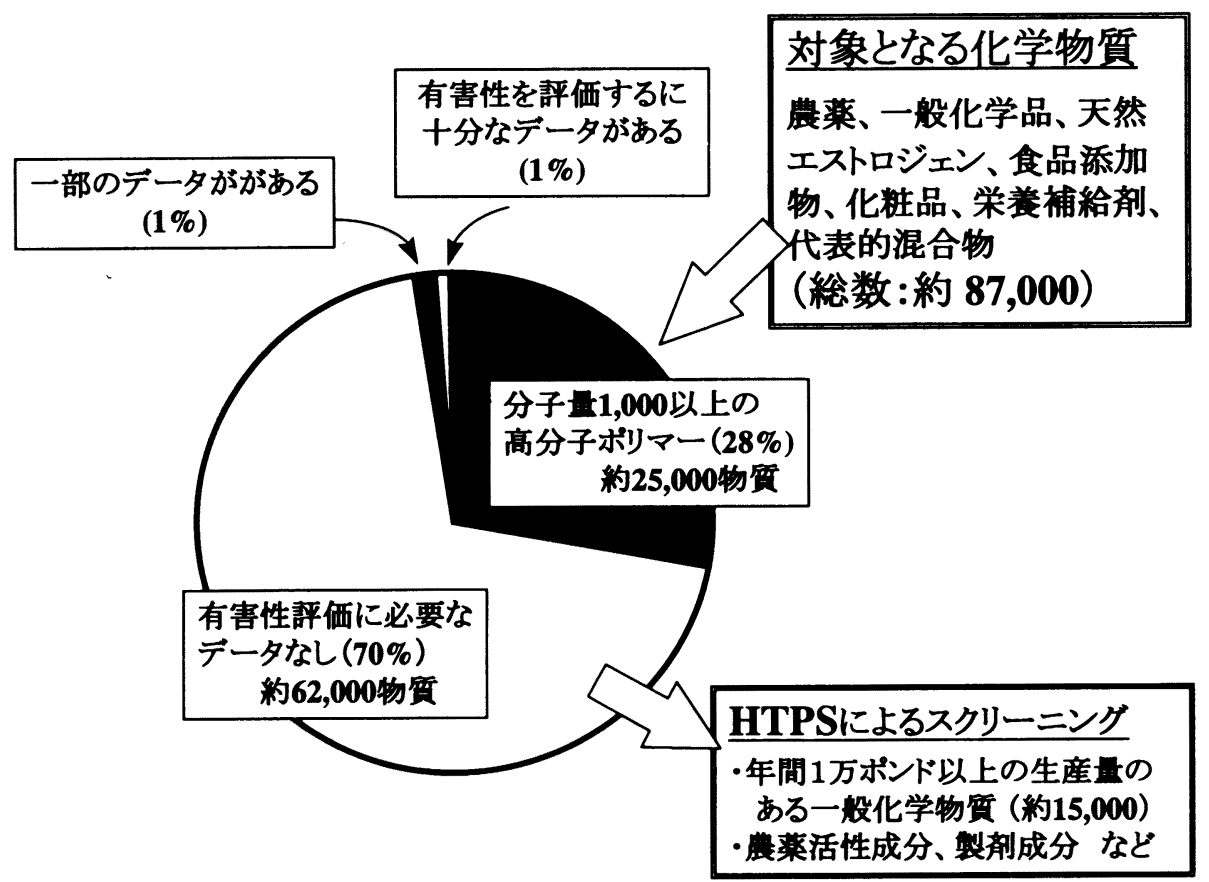

図 2 米国における試験対象化学物質の内訳

質の優先順位を決定し，(3)哺乳動物や鳥，魚などの繁 殖性試験等を実施し「内分泌攪乱作用」の有無を確認 する，と言うものである。米国では，対象となる化学 物質は, 約 87,000 あると考えられているが, そのうち 分子量 1,000 以上の高分子ポリマーは, 生物的に不活 性であるということで試験対象から除外されている。 残りの約 62,000 物質から内分泌㘔乱物質選別のため の試験に供する化学物質を絞り込むために, ホルモン 受容体との反応性を指標として簡便に選別することを 考えている (図 2)。これが高速実験ロボットを用いる HTPS (High Throughput Pre-screening) と称する 試験管内（in vitro）試験法であり，現在，その実用性 が検証されているところである。

\section{7. 化学工業界の取り組み状況}

内分泌攪乱物質問題に対しては, 日米欧の化学工業 界が連携して対応する体制が確立されており, 日本化 学工業協会もその枠組みのなかでこの問題に当たって いる。

\section{1 （社）日本化学工業協会（日化協）}

日化協は，比較的早い時期に内分泌挸乱物質問題が 欧米で問題となっていることを認識し, 1996 年 5 月, 化学物質の健康影響問題に精通する専門的な学識経験 者による科学的な事実関係の解明と対応策の検討を行
うべく, 通産省からの委託事業として(1)現状把握と評 価, (2)今後の調査・研究項目の抽出等を行い, 1997 年 3 月に報告書 ${ }^{8)}$ としてまとめた。これにより, コルボー ン博士らが主張する内分泌攪乱作用による野生生物お よびヒトへの影響のほとんどが PCB，DDT あるいは ダイオキシンによるものであることを明らかにした。

また, 1996 年 9 月, 内分泌攪乱物質問題に関する対 応組織として「エンドクリン・ワーキンググループ」 を設置し，(1)試験法の開発，(2)内分泌攪乱物質問題に 関する教育・広報, (3)関連情報, (4)規制動向について の調査等を開始し, 現在も継続中である。その後, 1998 年 3 月, 会員各社より総額 1.4 億円を募り, 日化協の 独自研究を開始した。その内容は, (1)内分泌攪乱物質 のスクリーニング手法に関する基礎検討および(2)内分 泌攪乱作用の発現メカニズムの解析を行うことである。

7.2 米国化学品製造者協会 (CMA：Chemical Manufacturers Association)

CMA は内分泌攪乱物質問題検討グループを設置し, 1996 年 6 月には内分泌挸乱物質問題の解明のための 研究プロジェクト (合計 85 万ドル) に着手した。現 在, これらを含め 3 年間で 400 万ドルのプロジェクト を推進中である。主な研究テーマは, (1)試験に供する 物質の優先順位を決めるための手法の開発, (2)既存の 試験方法の有效性評価とより効率的なスクリーニング 
手法の開発，(3)リスクアセスメント手法の開発および (4)内分泌影響のメカニズムの研究などである。

7.3 欧州化学工業連盟 (CEFIC: The European Chemical Industry Council)

CEFIC は, EC 委員会, 欧州環境庁, WHO 等と協力 して, 各種の調査・研究に着手している。また, CEFIC は 1996 年 6 月に内分泌挸乱物質検討グループを設置 すると共に, 向こう 3 年間で 575 万ドルの投入を決定 した。さらに, 1998 年 5 月には 700 万ドルの研究プロ グラムにも着手している。

なお，CEFICの優先研究テーマとしては，(1)スク リーニング手法の開発, (2)七ト影響に関する疫学調查, (3)環境生物への影響調査等が挙げられている。

\section{8. おわりに}

化学産業界は,「内分泌摫乱物質問題」については, レスポンシブル・ケアの精神から, 一般消費者をはじ めとするユーザーから発せられたあらゆる疑念に対し て誠意をもって応える必要がある。そのためには,「内 分泌攪乱物質」として疑われている化学物質の安全性 デー夕を整備したり，あるいは，関連する研究を推進 することは勿論のことである。現在，日本の化学産業 界では，このような化学物質に投げかけられている安 全性上の課題を総合的に研究するための体制の確立が 必要であるとの認識のもとに体制整備を進めていると ころであり, 世界の化学産業界あるいは内外の広い分 野の研究者とともに問題解決への努力を推進してゆく。

\section{参考資料}

1）「内分泌かく乱化学物質の健康影響に関する検討 委員会一中間報告書」(厚生省, 平成 10 年 11 月)

2) 西川洋三:「環境ホルモン問題は, 何が問題か (そ の4)」アロマティクス 51 巻, 118-127, 1999 年

3）「外因性内分泌攪乱化学物質問題への環境庁の対 応方針について一環境ホルモン戦略計画 SPEED '98」(環境庁, 平成 10 年 5 月)

4) "Special Report on Environmental Endocrine Disruption ; An Effects Assessment and Analysis" (Risk Assessment Forum U.S. EPA, February 1997)

5) "Report of the Working Group on Endocrine Disrupters of the Scientific Committee on Toxicity, Ecotoxicity and the Environment (CSTEE) of DGXXIV, Consumer Policy and Consumer Health Protection" (http : //europa. eu.int/comm/dg24/health/sc/sct/out37_en. html, March 1999)

6) "Endocrine Diruptor Screening and Testing Advisory Committee (EDSTAC) Final Report" (August 1998)

7) "Endocrine Disruptor Screening Program : Statement of Policy ; Notice" (Federal Register, Vol. 63, No.248, December 28, 1998)

8）「内分泌 (エンドクリン) 系に作用する化学物質に 関する調査研究」(社団法人日本化学工業協会, 平 成 9 年 3 月) 